\title{
In Vitro Studies on Sida cordifolia Linn for Anthelmintic and Antioxidant Properties
}

\author{
Rajesh Singh Pawa*, Ankit Jain, Preeti Sharma, Pradeep Kumar Chaurasiya, Pradeep Kumar Singour \\ Pharmacognosy and Phytochemistry Division, Faculty of Pharmacy, \\ VNS Group of Educations, VNS Campus, Vidya Vihar, India \\ E-mail: dr_pawar14@rediffmail.com \\ Received March 1, 2011; revised March 16, 2011; accepted April 22, 2011
}

\begin{abstract}
The present study was undertaken to evaluate in-vitro antioxidant and anthelmintic activity of ethanolic and aqueous extract from whole plant Sida cordifolia Linn (Malvaceae). The antioxidant activities are evaluated by various antioxidant assays like $\alpha, \alpha$-Diphenyl- $\beta$-picrylhydrazyl (DPPH) free radical scavenging, total reducing power, nitric oxide scavenging and hydrogen peroxide scavenging. The various antioxidant activities were compared to standard antioxidants such as ascorbic acid. The antioxidant activity of ethanolic extract is almost quantitatively equivalent to that of the standards used, ascorbic acid. The further anthelmintic activity of whole plant is investigated through using Indian earthworm (Pheretima posthuma) showed that it is one of the most important local medicinal plants both for ritual and ethnomedical practices. Various concentrations of ethanol and aqueous extract $(10,20,30,40 \mathrm{mg} / \mathrm{ml})$ of whole plant of Sida cordifolia Linn were tested in the bioassay, which involve determination of time of paralysis of the worms. Albendazole was included as reference standard. The most activity was observed with aqueous extract as compared to standard drug. The results from the above studies indicate that plant Sida cordifolia Linn. possesses potent antioxidant and anthelmintic activity.
\end{abstract}

Keywords: Albendazole, Anthelmintic, Antioxidant, Ascorbic Acid, DPPH, Pheretima posthuma, Sida cordifolia Linn

\section{Introduction}

Sida cordifolia Linn. (Malvaceae) syn. Country Mallow is a small, erect, downy shrub [1]. The leaves of the plant are cord ate-oblong or ovate-oblong and fruits with a pair of awns on each carpel. Roots of the plant which constitute a drug are $5-15 \mathrm{~cm}$ long with few lateral roots of smaller size. It is almost odorless with slightly bitter taste [2]. It grows well through the plains of India, especially, in damp climates. The shrub grows up to $0.75-1.5$ meters in height. The leaves are $2.5-7 \mathrm{~cm}$ long and 2.5 - 5 $\mathrm{cm}$ broad, with 7 - 9 veins. They are heart shaped, serrate and truncate. The flowers are small, yellow or white in color, solitary and axillaries. The fruits are moong-sized, 6 - $8 \mathrm{~mm}$ in diameter [3]. Bark is considered as cooling. It is useful in blood, throat, urinary system related troubles, piles, phthisis, insanity etc [4]. Franco et al. tested that rather than being a stimulant, Sida cordifolia actually acts as a depressant and decreases CNS activity [5]. It acts as a weight loss product is through its hypog- lycemic (blood sugar lowering) activity [6]. Fumaric acid isolated from S. cordifolia was reported to be hepatoprotective [7]. The roots of Sida cordifolia have been reported to possess astringent, diuretic and tonic properties. The drug has also demonstrated antibacterial, antiplaque and antifungal activities. Also it contains phytoconstituents such as pseudoephedrine, vaccine, asparagin, ephedrine, vascicinone, vaccine, vascinol. The present study was undertaken to validate its anthelmintic and antioxidant activity.

\section{Materials and Methods}

\subsection{Plant Material}

The whole plant of Sida cordifolia was identified, and collected in the month of October 2009 from the forest of Pachmarhi region, district Hoshangabad (Madhya Pradesh). The plant was authenticated by a Mr. S Rao, at Department of crop and herbal physiology college of 
agriculture, Jawaharlal Nehru Krishi Vishwavidhyala, Jabalpur (Voucher specimen No./HD/CHPY825).

\subsection{Drugs and Chemicals}

The following drugs and chemicals were used. Drug: Albendazole (BANDY, Mankind Pharma Ltd, New Delhi). Chemicals: petroleum ether $\left(40^{\circ} \mathrm{C}-60^{\circ} \mathrm{C}\right)$ A.R. (PCL, Pune), Ethanol A.R. (PCL, Pune), Dimethyl formamide (DMF) A.R. (PCL, Pune), Saline water (Claris Lifesciences Ltd., Ahmadabad), DPPH (Sigma Chemical Co.), Greiss reagent (Sigma Chemical Co.), Ascorbic acid (Sigma Chemical Co.) etc.

\subsection{Animals}

$3-5 \mathrm{~cm}$ in length and $0.1-0.2 \mathrm{~cm}$ in width Indian adult earthworm (Pheretima posthuma) collected from moist soil of Chambal fertilizer and chemical Ltd. MP Nagar, star Arcade zone-I, Bhopal.

\subsection{Preparation of Extracts}

The plant was washed and dried in shade followed by drying in hot air oven at low temperature then it was coarsely powdered. Plant powder (60 gm) subjected to successive solvent extraction in soxhlet apparatus using various solvents viz. petroleum ether $\left(40^{\circ} \mathrm{C}-60^{\circ} \mathrm{C}\right)$, ethanol and all the marc left was macerated with water. The petroleum ether was used to defat the marc and discarded. The ethanol and aqueous extracts were collected, concentrated and dried in open air to give percentage yield as $4.91 \% \mathrm{w} / \mathrm{w}$ and $26.24 \% \mathrm{w} / \mathrm{w}$ respectively [8].

\subsection{Phytochemical Studies}

Preliminary Phytochemical tests were performed as per methods described by Ansari and Khandelwal $[9,10]$. Ethanolic and aqueous extracts tested to reveal the presence of different primary and secondary metabolites [11].

\subsection{Anthelmintic Activity}

The Invitro trial for anthelmintic activity of ethanol and aqueous extract were conducted on earthworm Pheretima posthuma as per previous method [12]. Ethanol and aqueous extract of plant Sida cordifolia were dissolved in minimum amount of DMF and the volume was adjusted to $10 \mathrm{ml}$ with saline water. All drugs and extract solution were freshly prepared before starting the experiment.

\subsection{Description of Groups}

In each group, 6 earthworms were released into $10 \mathrm{ml}$ of desired formulations as follows: vehicle (5\% DMF in normal saline), Albendazole (10 - $40 \mathrm{mg} / \mathrm{ml})$, and various concentration $(10-40 \mathrm{mg} / \mathrm{ml})$ of ethanol extract or aqueous extract of plant Sida cordifolia in normal saline solution containing 5\% DMF. Observations were made for the time taken to paralysis and death of individual worm. Paralysis is said to occur when the worm is not able to move even in saline solution.

\subsection{Antioxidant Estimation}

The assessment of antioxidant activity was done through various in-vitro assays. The free radical scavenging activity of various concentrations of ethanol, aqueous extract of plant and ascorbic acid was measured in terms of hydrogen donating and radical-scavenging ability using the stable radical DPPH. Nitric oxide was generated from sodium nitroprusside and measured by the Greiss reaction. The activity was further confirmed by Reducing power assay and Hydrogen Peroxide Radical Scavenging Activity.

\subsection{Free Radical Scavenging Activity}

Antioxidant scavenging activity was studied using 1, 1-diphenyl-2-picrylhydrazyl free radical (DPPH) by the method of Brand William W. Various concentrations of test solutions in $0.1 \mathrm{ml}$ were added to $0.9 \mathrm{ml}$ of $0.1 \mathrm{mM}$ solution of DPPH in methanol. Methanol $(0.1 \mathrm{ml})$ was used as experimental control. After 30 min of incubation at room temperature, the reduction in the number of free radical was measured by reading the absorbance at 517 $\mathrm{nm}$. Ascorbic acid was used as reference standard. The scavenging activity of the samples corresponded to the intensity of quenching DPPH. The percent inhibition was calculated from the following equation: \% Inhibition = [(Absorbance of control - Absorbance of test sample)/ Absorbance control] $\times 100$.

\subsection{Reducing Power Assay}

The reducing power of plant extracts were determined by the method of Oyaizu. The capacity of extract to reduce the ferric-ferricyanide complex to the ferrous-ferricyanide complex of Prussian blue was determined by recording the absorbance at $700 \mathrm{~nm}$ after incubation. For this purpose, different concentrations of aqueous and ethanolic plant extract in $1 \mathrm{ml}$ of distilled water were mixed with phosphate buffer (2.5 ml, $0.2 \mathrm{M}, \mathrm{pH} \mathrm{6.6)}$ and potassium ferricyanide $(2.5 \mathrm{ml}, 1 \%)$. The mixture was incubated at $50^{\circ} \mathrm{C}$ for 20 minutes Aliquots $(2.5 \mathrm{ml})$ of Trichloroacetic acid (TCA, 10\%) were added to the mixture. The $2.5 \mathrm{ml}$ of solution was mixed with distilled water $(2.5 \mathrm{ml})$ and FeCl3 (0.5 ml, 0.1\%). The absorbance 
was measured at $700 \mathrm{~nm}$ by spectrophotometer. Increased absorbance of the reaction mixture indicates increased reducing ability.

\subsection{Nitric Oxide Scavenging Activity}

Nitric oxide scavenging activity was measured by the spectrometry method of Madan MP. Sodium nitropruside (5 mmol) in phosphate-buffered saline was mixed with a control without the test compound, but with an equivalent amount of methanol. Test solution of aqueous and ethanolic extracts at different concentrations were dissolved in methanol and incubated at $25^{\circ} \mathrm{C}$ for $30 \mathrm{~min}$. After $30 \mathrm{~min}, 1.5 \mathrm{ml}$ of the incubated solution was removed and diluted with $1.5 \mathrm{ml}$ of Griess reagent $(1 \%$ Sulphanilamide, 2\%) Phosphoric acid, and 0.1\% Naphthyl ethylenediamine dihydrochloride). The absorbance of the chromophore formed during the diazolization of the nitrite with sulphanilamide and the subsequent coupling with Naphthyl ethylenediamine dihydrochloride was measured at $546 \mathrm{~nm}$.

\subsection{Hydrogen Peroxide Radical Scavenging Activity}

The plant extract radical scavenging activity against hydrogen peroxide was determined using the method of Ruch et al. Samples of aqueous and ethanolic of different concentration were added to $0.1 \mathrm{M}$ phosphate buffer solution ( $\mathrm{pH} 7.4,3.4 \mathrm{ml}$ ), respectively, and mixed with 43 $\mathrm{mM}$ hydrogen peroxide solution $(0.6 \mathrm{ml})$. After $10 \mathrm{~min}$, the reaction mixture absorbance was determined at 230 $\mathrm{nm}$. The reaction mixture without sample was used as the blank. Ascorbic acid was used as a reference compound. The percentage inhibition activity was calculated [13].

\section{Results and Discussion}

The work presented here deals with preliminary phytochemical study, Anthelmintic and Antioxidant estimation of ethanolic and aqueous extract of whole plant Sida cordifolia Linn.

\subsection{Phytochemical Studies}

Tests for ethanol and aqueous extracts of whole plant Sida cordifolia showed presence of alkaloids, resins, steroids, proteins and flavonoids (Table 1).

\subsection{Anthelmintic Activity}

The results showed that aqueous extract of Sida cordifolia plant took least time to cause paralysis and death of the earthworms (Table 2). But the anthelmintic activity
Table 1. Preliminary phytochemical tests for ethanol and aqueous extracts.

\begin{tabular}{llcc}
\hline \multicolumn{1}{c}{ Chemical tests } & Phytochemicals & $\begin{array}{r}\text { Ethanol } \\
\text { extract }\end{array}$ & $\begin{array}{c}\text { Aqueous } \\
\text { extract }\end{array}$ \\
\hline Mayer's Test & Alkaloids & + & + \\
Killer Killani Test & $\begin{array}{l}\text { Glycosides } \\
\text { Tannins and phe- }\end{array}$ & - & - \\
Vanillin- HCl Test & $\begin{array}{l}\text { nolic compounds } \\
\text { Color detection }\end{array}$ & - & - \\
with ferric chloride & Resins & + & + \\
$\begin{array}{l}\text { Lead acetate test } \\
\text { Libermann-Bur } \\
\text { chard Test }\end{array}$ & Flavonoids & + & + \\
Ninhydrin Test & Steroids & + & + \\
$\begin{array}{l}\text { Biuret Test } \\
\text { Molisch's Test }\end{array}$ & Proteins & + & - \\
Solubility test & Farbohydrate & + & + \\
\hline
\end{tabular}

Table 2. Invitro anthelmentic activity of Sida cordifolia.

\begin{tabular}{lccc}
\hline $\begin{array}{c}\text { Test } \\
\text { samples }\end{array}$ & $\begin{array}{c}\text { Concentration } \\
\mathrm{mg} / \mathrm{ml}\end{array}$ & $\begin{array}{c}\text { Time taken } \\
\text { for paralysis } \\
\text { (minutes) }\end{array}$ & $\begin{array}{c}\text { Time taken for } \\
\text { death (mintues) }\end{array}$ \\
\hline Albendazole & 10 & $17.26 \pm 0.437^{*}$ & $26.35 \pm 1.026^{*}$ \\
& 20 & $10.00 \pm 0.25^{*}$ & $15.33 \pm 0.31^{*}$ \\
Aqueous & 30 & $4.37 \pm 0.15^{*}$ & $18.37 \pm 0.121^{*}$ \\
extract & 40 & $3.75 \pm 0.67^{*}$ & $8.51 \pm 1.231^{*}$ \\
& 10 & $19.18 \pm 1.38^{*}$ & $30.05 \pm 1.547^{*}$ \\
& 20 & $13.38 \pm 3.12^{* *}$ & $21.58 \pm 1.225^{*}$ \\
Ethanolic & 30 & $6.35 \pm 0.85^{*}$ & $20.00 \pm 4.24^{* *}$ \\
extract & 40 & $05.35 \pm 0.69^{*}$ & $10.23 \pm 1.025^{*}$ \\
& 10 & $27.00 \pm 0.895^{*}$ & $34.28 \pm 0.49^{*}$ \\
& 20 & $10.00 \pm 0.617^{*}$ & $23.45 \pm 0.89^{*}$ \\
& 30 & $8.27 \pm 0.327^{*}$ & $15.38 \pm 1.026^{*}$ \\
& 40 & $5.52 \pm 0.246^{*}$ & $18.00 \pm 4.05^{* *}$ \\
\hline
\end{tabular}

Control earthworms (Pheretima posthuma) were alive up to 24 hours of the experiment; All values represent mean _+ SEM; values are significant different from reference standard (albendazole) where, ${ }^{*} \mathrm{p}<0.01 ;{ }^{*} \mathrm{p}<0.05 \mathrm{v} / \mathrm{s}$ Albendazole, $\mathrm{SEM}=$ Standard Error Mean

is found to be present in both aqueous as well as ethanol extracts of Sida cordifolia plant [14].

\subsection{Antioxidant Activity}

\subsubsection{DPPH Radical Scavenging Activity}

The result of DPPH radical scavenging activity of the ethanolic and aqueous extract of Sida cordifolia with $\mathrm{IC}_{50}$ (\% Inhibition) is shown in Figure 1. The $\mathrm{IC}_{50}$ value of ethanolic and aqueous extract of Sida cordifolia was found to be $15 \mu \mathrm{g} / \mathrm{ml}$ and $16 \mu \mathrm{g} / \mathrm{ml}$ respectively where as the $\mathrm{IC}_{50}$ value of standard (Ascorbic acid) was found to be $8 \mu \mathrm{g} / \mathrm{ml}$. The results showed a significant $(\mathrm{p}<0.01)$ decrease in the concentration of DPPH radical due to the scavenging ability of both extracts as compared to standard (ascorbic acid). Thus, it can be concluded that both 


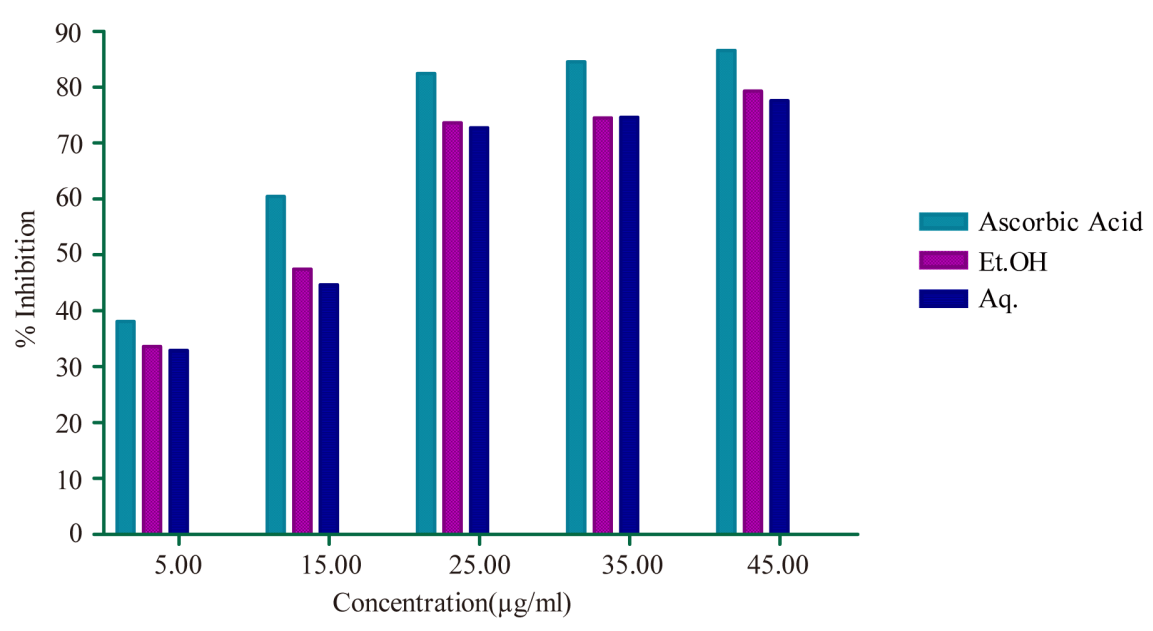

Figure 1. Invitro DPPH radical scavenging activity of ascorbic acid and various extracts of Sida cordifolia.

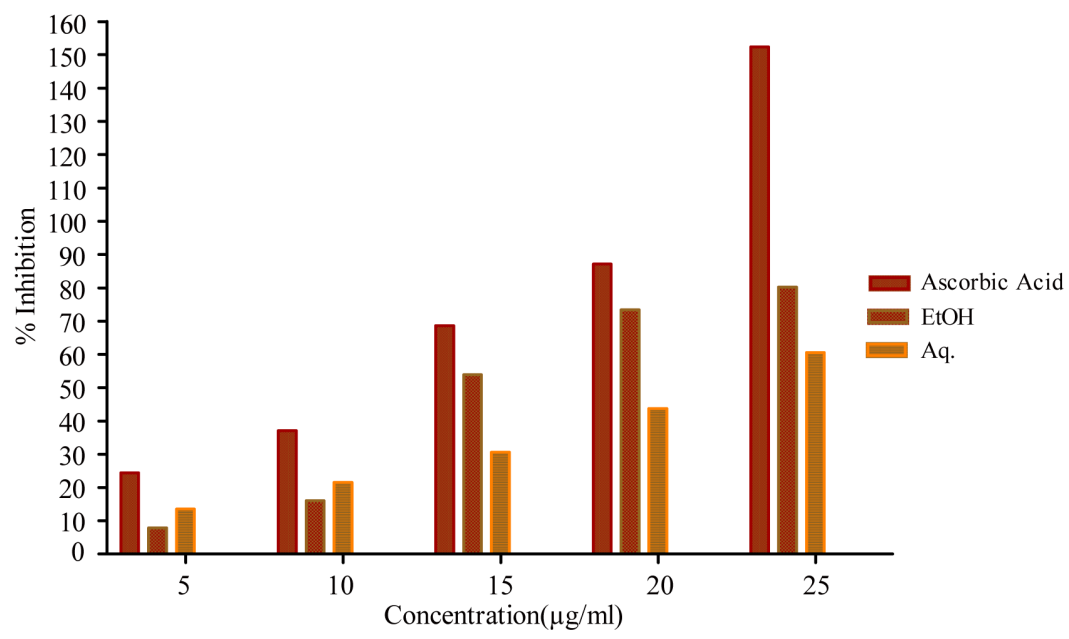

Figure 2. Invitro reducing power assay of ascorbic acid and various extracts of Sida cordifolia.

extracts of Sida cordifolia have antioxidant activity. But ethanolic extract was more significant as compared to aqueous extract [15].

\subsubsection{Reducing Power Assay Method}

The Reducing ability of ethanolic and aqueous extract of Sida cordifolia and ascorbic acid is shown in Figure 2. The $\mathrm{IC}_{50}$ value of ethanolic and aqueous extract of Sida cordifolia was found to be $16 \mu \mathrm{g} / \mathrm{ml}$ and $22 \mu \mathrm{g} / \mathrm{ml}$ respectively where as the $\mathrm{IC}_{50}$ Value of Ascorbic acid standard was found to be $11 \mu \mathrm{g} / \mathrm{ml}$. Both the extracts show significant $(\mathrm{p}<0.01)$ reducing property when compared with standard (ascorbic acid). Thus, it can be concluded that ethanolic extract show more potent reducing capacity as compared to aqueous extract [16].

\subsubsection{Nitric Oxide Radical Scavenging Activity}

The nitric oxide scavenging activity of ethanolic and aqueous extract of Sida cordifolia and ascorbic acid shown in Figure 3 illustrates the \% inhibition of nitric oxide generation by ethanolic and aqueous extract of Sida cordifolia. Ascorbic acid was used as a reference. The $\mathrm{IC}_{50}$ value of ethanolic and aqueous extracts were found to be $112 \mu \mathrm{g} / \mathrm{ml}$ and $117 \mu \mathrm{g} / \mathrm{ml}$, respectively, whereas the $\mathrm{IC}_{50}$ value of ascorbic acid was found to be $85 \mu \mathrm{g} / \mathrm{ml}$. The results indicate significant $(\mathrm{p}<0.01)$ decrease in the concentration of nitric oxide radical due to the scavenging ability of both ethanolic and aqueous extract as compared to standard (ascorbic acid). Both the extracts show significant scavenging activity but ethanolic extract showed more significant activity as compared to aqueous extract [17].

\subsubsection{Hydrogen Peroxide Radical Scavenging Activity}

Hydrogen peroxide scavenging activity of ethanolic and aqueous extract of Sida cordifolia and ascorbic acid are shown in Figure 4. The $\mathrm{IC}_{50}$ values for ethanolic and aqueous extracts were $183 \mu \mathrm{g} / \mathrm{ml}, 190 \mu \mathrm{g} / \mathrm{ml}$ whereas 


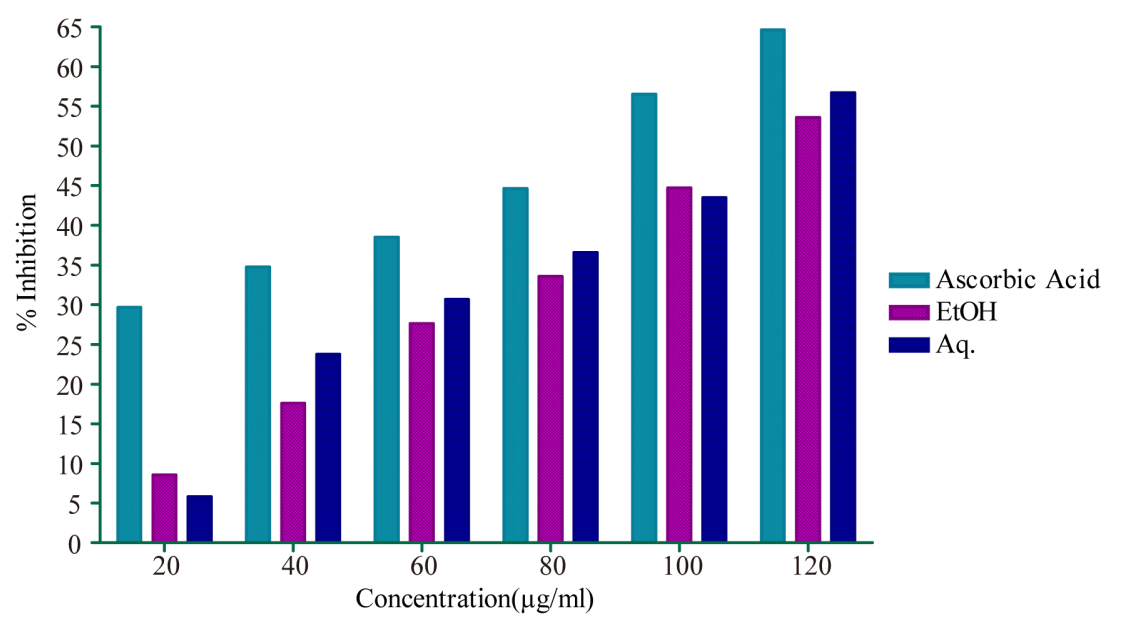

Figure 3. Invitro Nitric oxide scavenging activity of ascorbic acid and various extracts of Sida cordifolia.

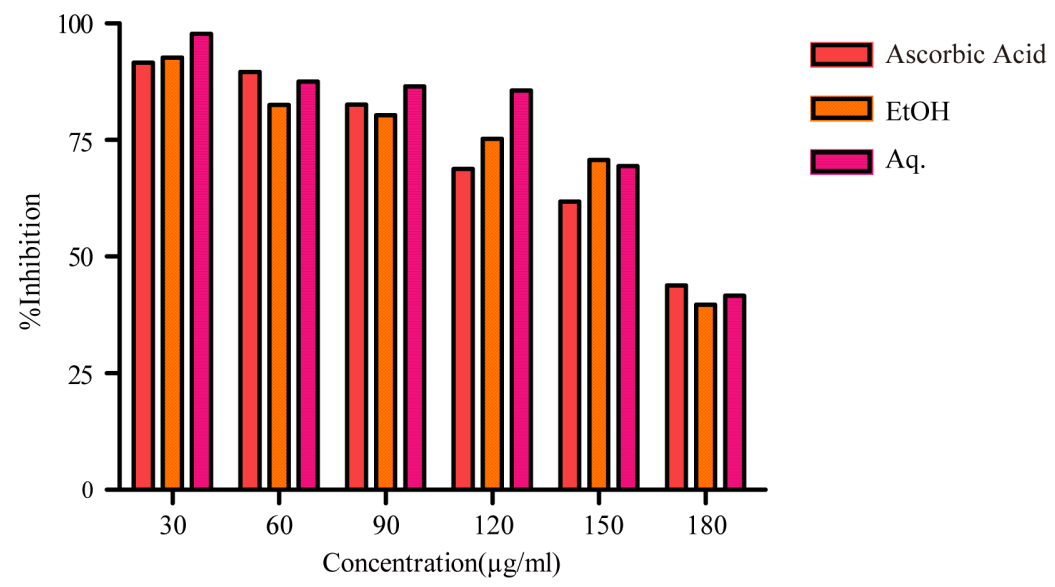

Figure 4. Invitro Hydrogen peroxide free radical scavenging activity of ascorbic acid and various extracts of Sida cordifolia.

$170 \mu \mathrm{g} / \mathrm{ml}$ was the value of ascorbic acid. It showed significant scavenging activity of hydroxyl radical generated from $\mathrm{H}_{2} \mathrm{O}_{2}$ system [18]. The results indicate that ethanolic and aqueous extract possess significant antioxidant activity $(\mathrm{p}<0.01)$. Comparison of hydroxyl radical activity of both ethanolic and aqueous extract with ascorbic acid showed ethanolic extract more significantly active than aqueous extract [19].

\section{Conclusions}

The present pharmacological studies on plant Sida cordifolia for anthelmintic and antioxidant activity reveal that the both extracts, i.e., ethanolic as well as aqueous show the anthelmintic activity. For antioxidant activity ethanolic extract was more significant as compared to aqueous extract due to the presence of various phytoconstituents such as alkaloid (asparagin, ephedrine, vascicinone, vascinol, pseudoephedrine), flavonoids (5,7- dihydroxy-3-isoprenyl flavone and 5-hydroxy-3-isoprenyl flavone) and phenolic compounds [20,21]. Thus, the whole plant of Sida cordifolia can be used as folklore medicine for the treatment of both causes.

\section{Acknowledgements}

The authors are thankful to Group director of VNS Institute of Pharmacy and Research Centre for financial support, providing necessary facilities, chemicals and other needful environment for successful completion of this research.

\section{References}

[1] J. B. Harbone, "Phytochemical Methods: A Guide to Modern Techniques of Analysis," Chapman and Hall Publishers, London, 1973, pp. 4-7.

[2] P. K. Mukherjee, “Quality Control of Herbal Drugs,” 1st Edition, Bussiness Horizon, Pharmaceutical Publishers, New Delhi, 2002, pp. 380-422. 
[3] G. W. Thorn, R. D. Adams, E. Braunwald, K. J. Isselbacher and R. G. Peterdrof, "Harrison's Principles of Internal Medicine,” McGraw Hill Co., New York, 1977, pp. 1088-1089.

[4] Z. Vigar, "Atlas of Medicinal Parasitology,” P. G. Publication House, Singapore, 1984, pp. 216-217.

[5] S. A. Nirmal, G. Malwadkar and R. B. Laware, "Anthelmintic Activity of Pongamia Glabra," Songklanakarin Journal of Science and Technology, Vol. 29, No. 3, 2007, pp. 755-757.

[6] H. S. Ansari, "Essentials of Pharmacognosy," Nirali Prakashan, Delhi, 2001, pp. 588-591.

[7] K. R. Khandelwal, "Practical Pharmacognosy,” Ninth Edition, Nirali Prakashan, Delhi, 2002, pp. 149-153.

[8] V. D. Rangari, "Pharmacognosy and Phytochemistry, Part II,” First Edition, 2009, pp. 274-275.

[9] The Indian Materia Medica. "With Ayurvedic, Unani and Home Remedies,” Vol. 3, 1993, pp. 1134-1137.

[10] P. Sebastian, "Ayurvedic Medicine," Elsevier Health Sciences, 2006.

[11] S. P. Agharkar, "Medicinal Plants of Bombay Presidency. Pbl,” Scientific Publishers, Jodhpur, 1991, pp. 194-195.

[12] C. I. F. Franco, L. C. S. L. Morais, L. J. Quintans-Junior, R. N. Almeida and A. R. Antoniolli, "CNS Pharmacological Effects of the Hydroalcoholic Extract of Sida Cordifolia L. Leaves,” Journal of Ethnopharmacology, Vol. 98, No. 3, April 2005, pp. 275-279. doi:10.1016/j.jep.2005.01.008

[13] V. R. Kanth and P. V. Diwan, "Analgesic, Antiinflammatory and Hypoglycaemic Activities of Sida Cordifo- lia,” Phytotherapy Research, Vol. 13, No. 1, 1999, pp. 75-77. doi:10.1002/(SICI)1099-1573(199902)13:1<75::AID-PT R387>3.3.CO;2-6

[14] S. B. Kosalge and R. A. Fursul, "Investigation of in Vitro Anthelmintic Activity of Thespesia Lampas (cav.)," Easian Journal of Pharmaceutical and Clinical Research, Vol. 2, No. 2, April-June 2009, pp. 69-71.

[15] R. S. Kumar and S. H. Mishra, "Anti-Inflammatory and Hepatoprotective Activities of Sida Rhombifolia Linn," Indian Journal of Pharmacology, Vol. 29, No. 2, 1997, pp. 110-116.

[16] W. B. William, M. E. Cuvelier and C. Berset, "Use of Free Radical Method to Evaluate Antioxidant Activity," Food Science Technology, Vol. 28, No. 1, 1995, pp. 2530.

[17] M. Oyaizu, "Studies on Products of Browning Reactions: Antioxidant Activities of Products of Browning Reaction Prepared from Glucose Amine,” Japanese Journal of Nutrition, Vol. 44. 1986, pp. 307-315.

[18] M. P. Madan, G. Raghavan, A. K. Singh and P. Palpu, "Free Radical Scavenging Potential of Saussare Costus," Acta Pharma, Vol. 55, 2005, pp. 297-304.

[19] R. J. Ruch, S. U. Chug and J. E. Klaunig, "Spin Trapping of Superoxide and Hydroxyl Radicals," Methods in Enzymology, Vol. 105, 1984, pp. 198-209. doi:10.1016/S0076-6879(84)05026-6

[20] http://www.docstoc.com/docs//38801351/sidacordifolia

[21] R. K. Sutradhar, A. K. M. Rahman, M. U. Ahmad and S. C. Bachar, "Bioactive Flavones of Sida cordifolia," Phytochemistry Letters, Vol. 1, No. 4, December 2008, pp. 179-182. 